\title{
Postseismic fluid discharge chemically recorded in altered pseudotachylyte discovered from an ancient megasplay fault: an example from the Nobeoka Thrust in the Shimanto accretionary complex, SW Japan
}

Ryota Hasegawa ${ }^{1}$, Asuka Yamaguchi ${ }^{1 *}$ (D, Rina Fukuchi ${ }^{1}$, Yohei Hamada ${ }^{2}$, Nobuhiro Ogawa ${ }^{1}$, Yujin Kitamura ${ }^{3}$, Gaku Kimura ${ }^{4}$, Juichiro Ashi ${ }^{1}$ and Tsuyoshi Ishikawa ${ }^{2}$

\begin{abstract}
Megasplay fault branching from plate boundaries of subduction zones is thought to be important sources of earthquakes and tsunamis. In this study, we performed structural and geochemical analyses on a fossilized megasplay fault (the Nobeoka Thrust of the Shimanto accretionary complex) to understand fluid-rock interaction and how the splay fault plays a role in fluid flow in the seismogenic zone. As a result of structural observations, we report that the principal slip zone (PSZ) of the Nobeoka Thrust is composed of foliated cataclasite originating from a sandstone-shale mélange and includes a thin $(\sim 1.5 \mathrm{~mm}$ thick) pseudotachylyte layer. Major and trace element composition analysis and EPMA element mapping revealed that the pseudotachylyte is enriched in Li and Cs within the PSZ, as well as in the slip zone of a minor fault in the footwall. Li and Cs enrichment in pseudotachylyte is interpreted as a result of fluid-rock interaction in the postseismic stage, because such an anomaly only results from a large fluid/rock ratio $\left(R>512-24\right.$ at $\left.250-350^{\circ} \mathrm{C}\right)$ under the influence of Li- and Cs-enriched fluids. The amount of fluid that reacted with the pseudotachylyte is estimated to be $1.78 \times 10^{0}$ to $7.61 \times 10^{3} \mathrm{~m}^{3}$.
\end{abstract}

Keywords: Megasplay fault, Fluid-rock interaction, Pseudotachylyte, Hydrothermal alteration

\section{Introduction}

Megasplay fault branching from plate boundaries is thought to be one of the origins of subduction zone earthquakes. For example, the megasplay fault of the Nankai Trough was the source of the 1944 Tonankai earthquake and the associated tsunami (Park et al. 2002). In order to understand the mechanism of the occurrence of earthquakes and tsunamis, it is important to understand the factors involved in the weakening of a

\footnotetext{
*Correspondence: asuka@aori.u-tokyo.ac.jp

${ }^{1}$ Atmosphere and Ocean Research Institute, The University of Tokyo, 5-1-5 Kashiwanoha, Kashiwa, Chiba 277-8564, Japan

Full list of author information is available at the end of the article
}

megasplay fault and the change in fault properties before and after the earthquake.

The role of fluid has been discussed as one of the factors controlling the seismic cycle and fault weakening. Sibson (1973) proposed thermal pressurization as a factor in dynamic fault weakening during an earthquake. From theoretical and experimental investigations (e.g., Mase and Smith 1987; Rice 2006; Bizzarri and Cocco 2006), thermal pressurization is assumed to be one of the factors that causes a dynamic fault weakening at the time of an earthquake. Furthermore, Sibson (1975) proposed a seismic pumping model, i.e., fluid flows into cracks formed by faulting within a high pore pressure zone. Such fluid flow occurs every time faulting occurs. 
In the off-Kumano area of the Nankai Trough, megasplay faults are clearly imaged by seismic profiles, and the existence of a high pore pressure zone along the deep portion of the megasplay fault has been documented (Park et al. 2002). In addition, Park et al. (2010) show the low-velocity zone beneath the accretionary prism extending from the deformation front of the Nankai Trough to the outer ridge. Tsuji et al. (2014) showed that the distribution of the megasplay fault is related to the high pore pressure zone. These studies support the hypothesis of a close relationship between fault behavior and pore pressure in megasplay faults in subduction zones.

However, the involvement, transfer, and flow rate of fluid during and after movement along a megasplay fault have not yet been assessed. Since the formation of cracks due to faulting generates pathways for fluids inside the accretionary prism, their origins and distributions are thought to greatly influence the fluid flow and pore pressure. Therefore, it is important to understand the record of fluid flow in seismically active fault zones.

In this study, we investigated the record of fluid-rock interaction by applying geochemical analysis to the fault rocks of the Nobeoka Thrust in the Shimanto accretionary complex, Japan, which is presumed to be an inland analog of a megasplay fault in a subduction zone setting. From this research, we aim to clarify the fluid volume that likely reacted with fault rocks and the role that the megasplay fault plays in fluid flow in fault zones and subduction zones.

\section{Geological setting and borehole core lithology Geological setting}

The Nobeoka Thrust in Kyushu, southwest Japan, is a low-angle thrust that subdivides the Shimanto accretionary complex in Kyushu into northern (Cretaceous and Paleogene) and southern (Paleogene) subbelts (Fig. 1a). The hanging wall and the footwall of the Nobeoka Thrust are composed of different lithologies and metamorphic grades, and their maximum burial temperatures estimated from vitrinite reflectance analysis are approximately $320-330^{\circ} \mathrm{C}$ and $250-270^{\circ} \mathrm{C}$, respectively. Murata (1998) suggested that the Nobeoka Thrust dips $\sim 10^{\circ} \mathrm{N}-$ $\mathrm{NE}$, and, assuming that the temperature gap between the hanging wall and footwall was formed by displacement along the fault, the total displacement is estimated to be $\sim 10 \mathrm{~km}$, which is based on the dip of the Nobeoka Thrust and a pre-thrusting geothermal gradient of 28$47^{\circ} \mathrm{C} / \mathrm{km}$ (Kondo et al. 2005). It is presumed from the thermal structure that the Nobeoka Thrust is a megasplay fault activated in the deep part of a seismogenic zone.

The hanging wall of the Nobeoka Thrust is part of the Eocene Kitagawa Group, a largely phyllitic unit.

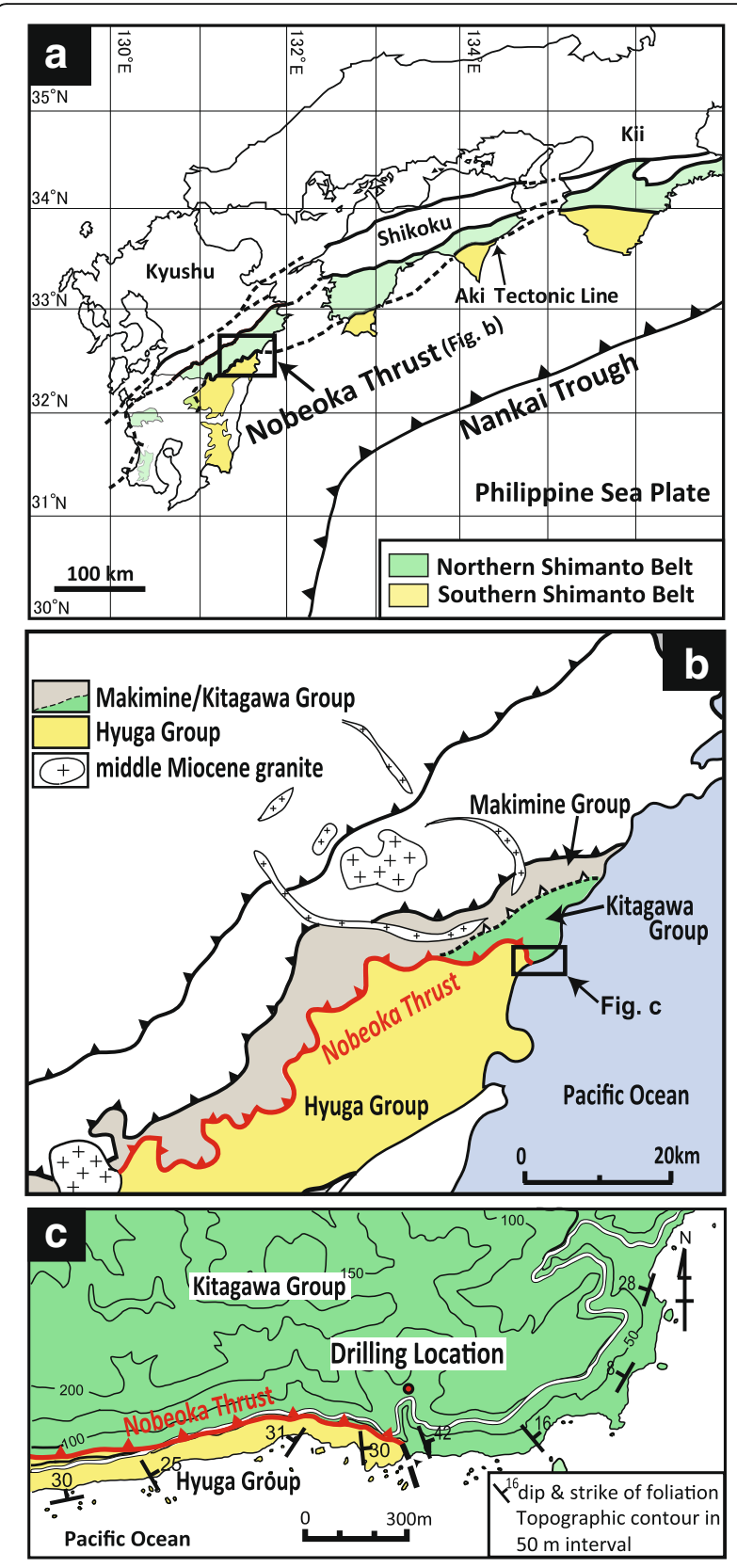

Fig. 1 Geologic setting of the Nobeoka Thrust. a Geologic setting of the Nobeoka Thrust and distribution of the Shimanto Belt in southwest Japan. b A simplified geologic map of the Shimanto Belt in northeast Kyushu, modified from Murata (1998). c Geologic map of the studied area and the locality of the drilling site (dot) for the hanging wall of the Nobeoka Thrust (modified from Kondo et al. 2005; Kimura et al. 2013; Hamahashi et al. 2013)

However, in places, sandstone and shale layers are evident (Kondo et al. 2005). In the hanging wall, within the range of $50 \mathrm{~m}$ from the PSZ, shear zones composed of cataclasite (in part, pseudotachylyte formed subsequent to implosion breccia) along with quartz, calcite, and ankerite veins are observed every several tens of 
centimeters to several meters (Okamoto et al. 2006, 2007). The mineral vein formation temperature using $\mathrm{H}_{2} \mathrm{O}-\mathrm{CH}_{4}$ fluid inclusions is estimated to be $\sim 230-260^{\circ}$ $\mathrm{C}$ and the pore pressure is estimated to be $\sim 175 \mathrm{MPa}$. The number of cumulative shear planes and the amount of strain increases toward the PSZ (Kimura et al. 2013).

In the coastal outcrop of the Nobeoka Thrust, the principal slip zone (PSZ) is approximately $20-40 \mathrm{~cm}$ thick. It contains sandstone and quartz vein clasts and is highly deformed compared to surrounding rocks. The rocks in the coastal outcrop have been multiply deformed, and it is difficult to decipher their deformational history. However, slickenlines within the PSZ show top to the SSE, the same as those in the hanging wall and footwall. This slip direction is regarded as the shear sense for the main thrust (Kondo et al. 2005). Fukuchi et al. (2014) measured illite crystallinity and illite peak intensity using bulk samples taken from a borehole. The results of Fukuchi et al. (2014) indicate that plagioclase breakdown was accompanied by local hydrothermal alteration and formation of white mica (i.e., illite) along the PSZ.

The Eocene-Oligocene Hyuga Group comprises the footwall of the Nobeoka Thrust. The lithology of the Hyuga Group near the thrust is mélange consisting of sandstone and basalt blocks and the remnants of volcanic ash layers in a shale matrix (Kondo et al. 2005). At the coastal outcrop of the Nobeoka Thrust, $\sim 20 \mathrm{~m}$ beneath the PSZ of the Nobeoka Thrust, a zone, $\sim 0.1-3$ $\mathrm{m}$-thick, of cataclasite with random fabric is observed. In the range of $20-50 \mathrm{~m}$ from the PSZ, N-S striking shear planes with top to the SSE slip directions are key components of a composite planar fabric. Within the shear zone, mineral fillings within opening (mode I) and

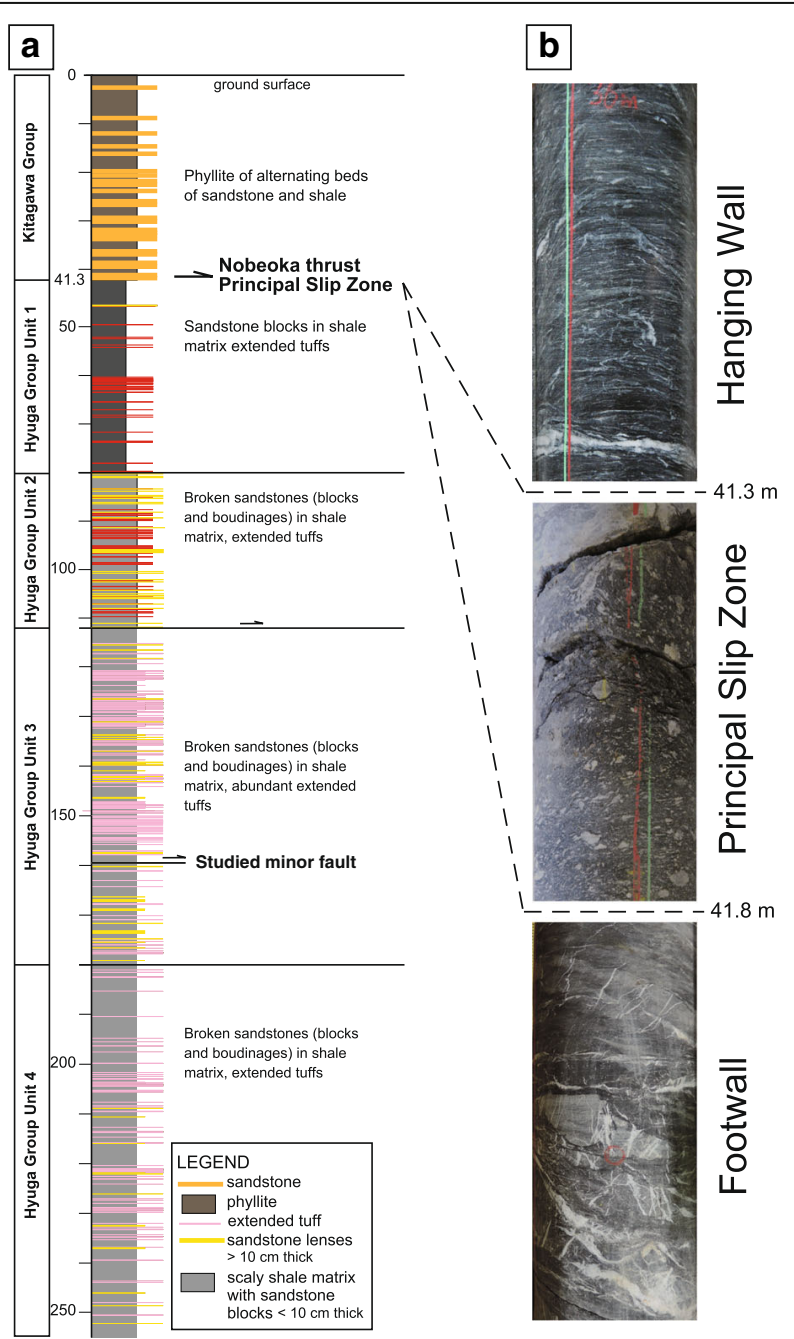

Fig. 2 Borehole core lithology and core photos. a Integrated columnar section showing core lithology (modified from Fukuchi et al. 2014). b Borehole core photos representing the hanging wall, principal slip zone and footwall. Depth of the core photos of hanging wall, principal slip zone and footwall is $36.00-36.18,41.30-41.47$, and $126.37-127.50 \mathrm{~m}$ below the ground surface, respectively 
shearing (modes II and III) cracks include quartz, calcite, and ankelite. Such infillings imply that the redox state of fluids passing through the shear zone changed during the earthquake cycle (Yamaguchi et al. 2011). Among these mineral veins, mode I cracks apparently formed after seismic slip events (Otsubo et al. 2016; Kawasaki et al. 2017). In addition, a model for calculating the timescale of occlusion of quartz veins was developed (Saishu et al. 2017). From this research, the timescale required for formation of a quartz vein near the Nobeoka Thrust and the seismic cycle of the Nankai Trough were found to be similar. In addition, since the temperature obtained from the fluid inclusions (Kondo et al. 2005) is higher than the temperature obtained from vitrinite reflectance (Sakaguchi 1999; Ohmori et al. 1997), warm fluid at a temperature higher than that of the host rocks must have moved through the shear zone (Kondo et al. 2005). Hence, the shear zone of the Nobeoka Thrust was formed in a place where fluids existed in abundance.

\section{Borehole core sample}

A borehole core was excavated from the outcrop east of the Nobeoka Thrust by the Nobeoka Thrust Drilling project (NOBELL) in 2011 (Figs. 1b, c and 2). Over the $255 \mathrm{~m}$ of recovered borehole core, the hanging wall (Kitagawa Group) reaches to a depth of $41.3 \mathrm{~m}$, the PSZ corresponds to depths of 41.3 to $41.8 \mathrm{~m}$ (Fig. 2), and the footwall (Hyuga Group) extends from the $41.8 \mathrm{~m}$ to 255 $\mathrm{m}$. The footwall block from 41.8 to $\sim 80 \mathrm{~m}$ experienced considerable deformation, and at depths $>80 \mathrm{~m}$ underwent even stronger deformation compared to the hanging wall. Fault breccia and fault gouge often occur in the footwall.

Hamahashi et al. (2013, 2015) carried out structural, geophysical logging, and physical property (resistivity, porosity, P- and S-wave velocities) analyses of the borehole. The deformation style is regulated by lithology and physical property contrasts and revealed that fault zones of various thicknesses exist throughout the borehole. In addition, studies to determine changes in metamorphism, porosity, and rock strength with increasing burial

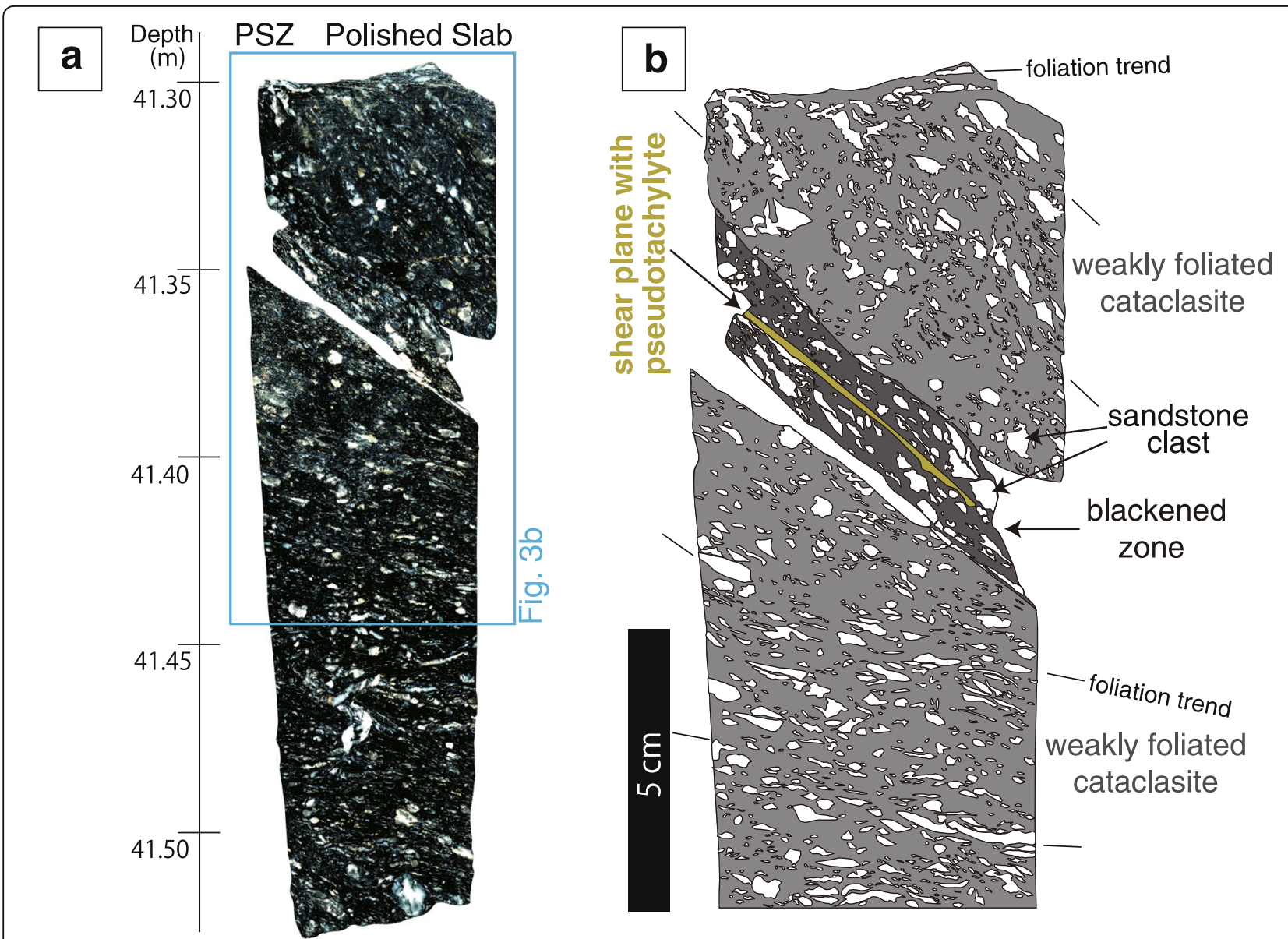

Fig. 3 Internal structure of the PSZ. a A photograph of polished slab of the PSZ. Polished slab is $24 \mathrm{~cm}$ long and $5-7 \mathrm{~cm}$ wide. Blue square shows the area of the sketch (Fig. 2b). $\mathbf{b}$ Sketch of polished slab of the PSZ. PSZ is composed of foliated cataclasite including sandstone clast. Foliated cataclasite is truncated by sharp shear plane accompanying blackened zone. The shear plane is composed of pseudotachylyte 
depth from triaxial compression tests using the hanging wall and footwall samples have been undertaken (Kitajima et al. 2017). Also, changes in the directions of the principal stress axes before and after movements along the Nobeoka Thrust were detected by paleostress analysis (Kawasaki et al. 2017).

In this study, we focus on the PSZ as an end member of large-slip fault rock in the Nobeoka Thrust. We also describe a typical minor, possibly small-slip fault located at a depth of $154.75 \mathrm{~m}$ (Fig. 2), which bounds adjacent foliated cataclasite and brecciated zone (Hamahashi et al. 2015).

\section{Methods/Experimental}

\section{Structural observation}

A polished slab was prepared by dividing the upper, highly deformed $20 \mathrm{~cm}$ of the $50 \mathrm{~cm}$ thick PSZ (depth 41.3-41.8 $\mathrm{m}$ ) into three sections in the longitudinal direction and polishing one third of the central part with \#800 grit (Fig. 3). In addition, thin sections were also prepared from the opposite side of polished slabs, as well as a minor fault located at a depth of $154.75 \mathrm{~m}$ (Fig. 2). By using these polished slabs and thin sections, we carried out microstructural observation.

\section{Microtextural observation (SEM) and chemical mapping (EPMA)}

We performed microtextural observation by using the FE-SEM (Hitachi High Technologies S-4800) installed at the Atmosphere and Ocean Research Institute (AORI), the University of Tokyo, Japan. An Electron Probe Microanalyzer (EPMA, JEOL JXA-8900), also installed at the Atmosphere and Ocean Research Institute, was used for element mapping of the thin sections. Chemical mapping analyses were performed on $2 \mathrm{~cm}^{2}$ and $2 \mathrm{~mm}^{2}$ square carbon-coated thin sections of the fault rock within the PSZ (Figs. 4 and 6). We analyzed ten major elements, $\mathrm{Si}, \mathrm{Ti}, \mathrm{Al}, \mathrm{Fe}, \mathrm{Mn}, \mathrm{Mg}, \mathrm{Ca}, \mathrm{Na}, \mathrm{K}$, and $\mathrm{P}$, with an acceleration voltage of $15.0 \mathrm{kV}$ and probe current of $1.216 \times 10^{-8} \mathrm{~A}$.

\section{Major and trace element composition analyses (ICP-MS and XRF)}

Powdered samples taken from the borehole core and rock chips prepared for thin sections were analyzed for major and trace element compositions. Micro-sampling was carried out on the rock chips using a micro-milling apparatus equipped with a single-crystal diamond bit (GEOMILL 326) installed in the Kochi Core Center (KCC). Typically about one milligram of rock powder was collected by GEOMILL 326. We focused on the PSZ and the minor fault within the footwall of the Nobeoka Thrust (Figs. 2 and 3). Locations of sampling points are shown in Additional file 1: Additionally, $\geq 3 \mathrm{~g}$ of rock chips sampled across the PSZ (from depths 35.0 to $48.75 \mathrm{~m}$ ) were also analyzed for major and trace element compositions (Additional file 2 and 3).

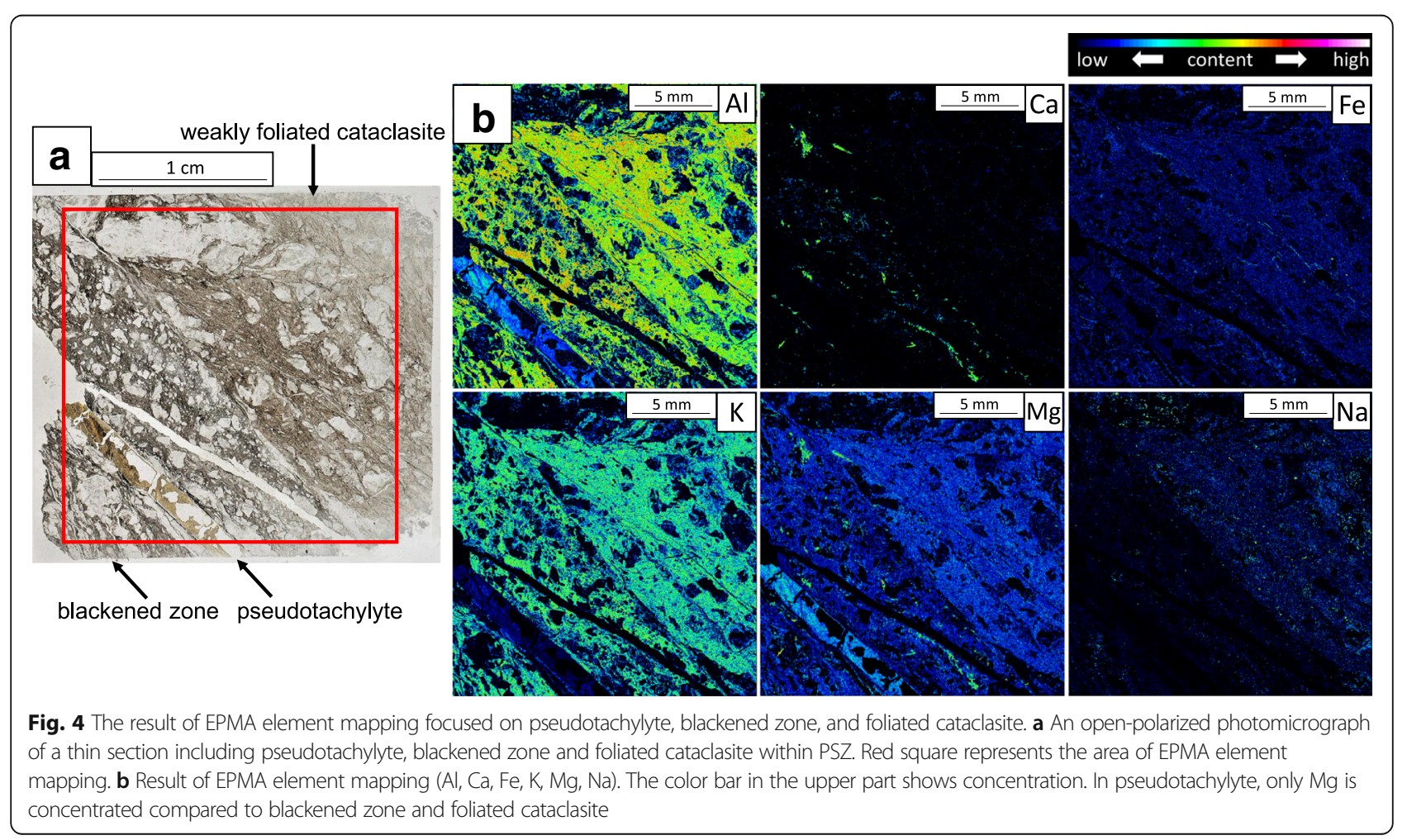




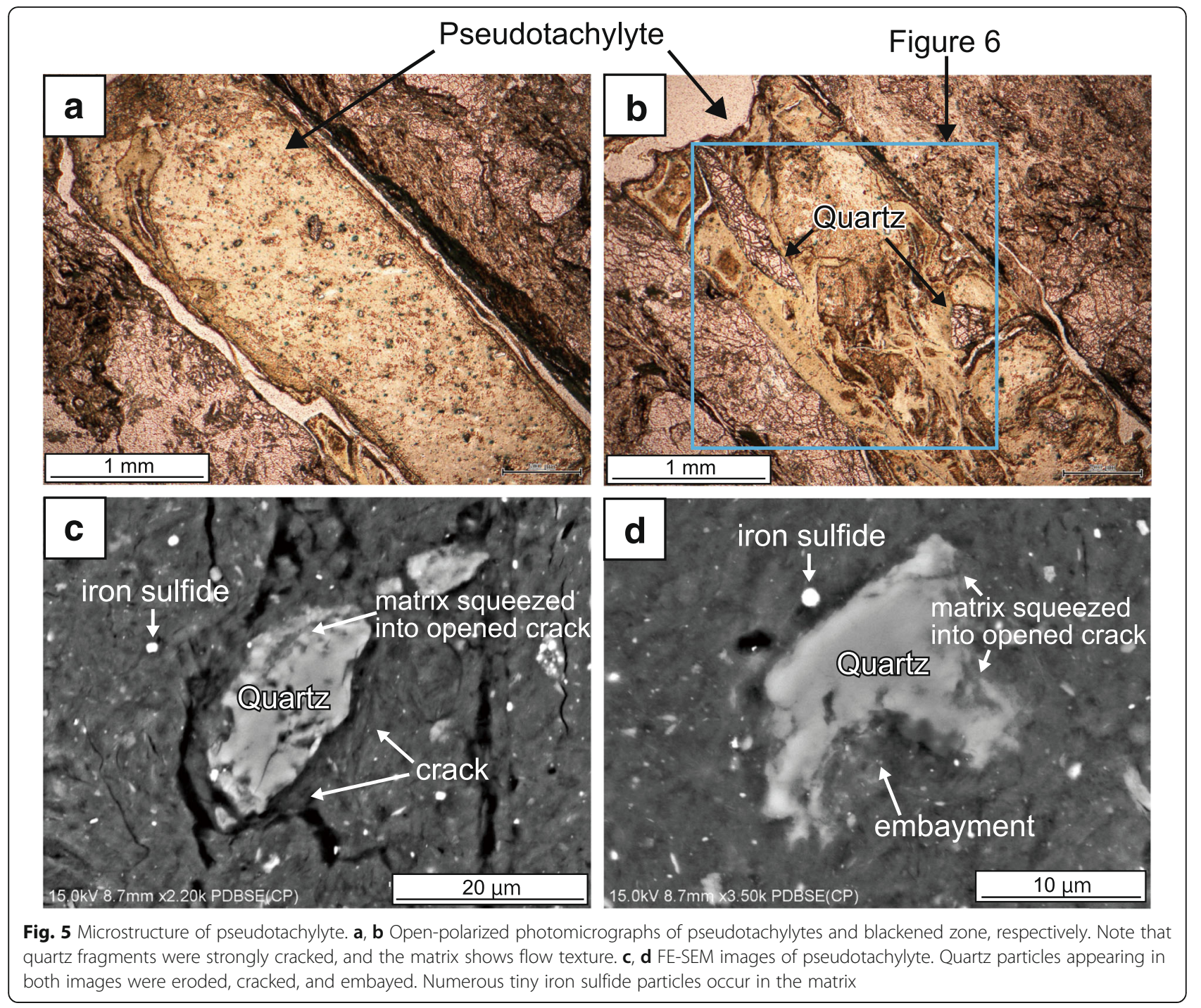

We performed acid digestion and inductively coupled plasma-mass spectrometry (ICP-MS) analysis on powder samples. First, the powdered sample was decomposed with $\mathrm{HNO}_{3}$ and $\mathrm{HF}$ at $120^{\circ} \mathrm{C}$ and evaporated to dryness. Subsequently, $\mathrm{HClO}_{4}$ was added to the dried sample and evaporated to dryness at $180^{\circ} \mathrm{C}$, and then $\mathrm{HNO}_{3}(6 \mathrm{M})$ was added to the dried sample and evaporated again. The dried sample was finally dissolved with a mixed acid composed of $0.15 \mathrm{M}$ $\mathrm{HNO}_{3}$ and $0.015 \mathrm{M}$ HF containing $10 \mathrm{ppb}$ indium internal standard. Concentrations of major and trace element concentrations were determined by ICP-MS (Agilent technology 7700x) at KCC.

The concentration of $\mathrm{SiO}_{2}$ was not directly measurable by ICP-MS because of volatilization of $\mathrm{SiF}_{4}$ during $\mathrm{HF}-\mathrm{HNO}_{3}$ digestion. However, the size of the sample collected with the micro-milling process was too small to be analyzed by X-ray fluorescence (XRF). Therefore, we estimated the $\mathrm{SiO}_{2}$ value as follows. We measured major element concentrations $\left(\mathrm{SiO}_{2}\right.$, $\mathrm{TiO}_{2}, \mathrm{Al}_{2} \mathrm{O}_{3}, \mathrm{Fe}_{2} \mathrm{O}_{3}, \mathrm{MnO}, \mathrm{MgO}, \mathrm{CaO}, \mathrm{Na}_{2} \mathrm{O}, \mathrm{K}_{2} \mathrm{O}$, and $\mathrm{P}_{2} \mathrm{O}_{5}$ ) in three samples PSZ_1, PSZ_2, and PSZ_3. The sizes of each of these three samples were large enough to be analyzed by XRF (Rigaku ZSX Primus II) as well as by ICP-MS. PSZ_1, PSZ_2, and PSZ_3 were taken from the polished slab of PSZ. PSZ_1 was extracted from the upper part of PSZ, PSZ_2 was taken from a section located immediately under PSZ_1, and PSZ_3 was collected from near the center of the polished slab (Additional file 1c). By dividing the major oxide concentration obtained by $\operatorname{ICP}-\mathrm{MS}\left(C_{\mathrm{i}}\right)$ by the value obtained by XRF $\left(C_{\mathrm{x}}\right)$, the correction factor $C_{\mathrm{i}} / C_{\mathrm{x}}$ can be obtained. We estimated $\mathrm{SiO}_{2}$ values for the micro-milled samples by 
subtracting the sum of the corrected nine major oxide concentrations obtained by ICP-MS plus average water content of PSZ_1, 2, and 3, from $100 \mathrm{wt} \%$.

\section{Results}

\section{Microstructure of PSZ}

Visual inspection of a polished slab of the PSZ revealed particle size reduction of sandstone clasts (Figs. 2 and 3). Additionally, the PSZ exhibits the structure of a weekly foliated cataclasite. The weekly foliated cataclasite is truncated by a sharp shear plane (thickness of 1.0-1.5 $\mathrm{mm}$ ) adjacent to a blackened zone (thickness of $\sim 7.0$ $\mathrm{mm})$ (Fig. 3). The shear plane dips steeper ( $30^{\circ}$ eastward) than the surrounding weekly foliated cataclasite, and the orientation is consistent with the dominant orientation of the shear planes developed in the footwall. In the upper part of the PSZ, closer to the shear plane, the weakly developed foliation changes from high to low angle. Fragments in the weakly foliated cataclasite are mainly composed of quartz and have a uniform particle size regardless of the distance from the sharply defined shear plane.

\section{Pseudotachylyte}

The filling material of the sharply defined shear plane has characteristic features of melt-origin pseudotachylyte (Fig. 3). Hereafter, we use "pseudotachylyte" for the






\section{Pseudotachylyte and Blackened zone in PSZ}
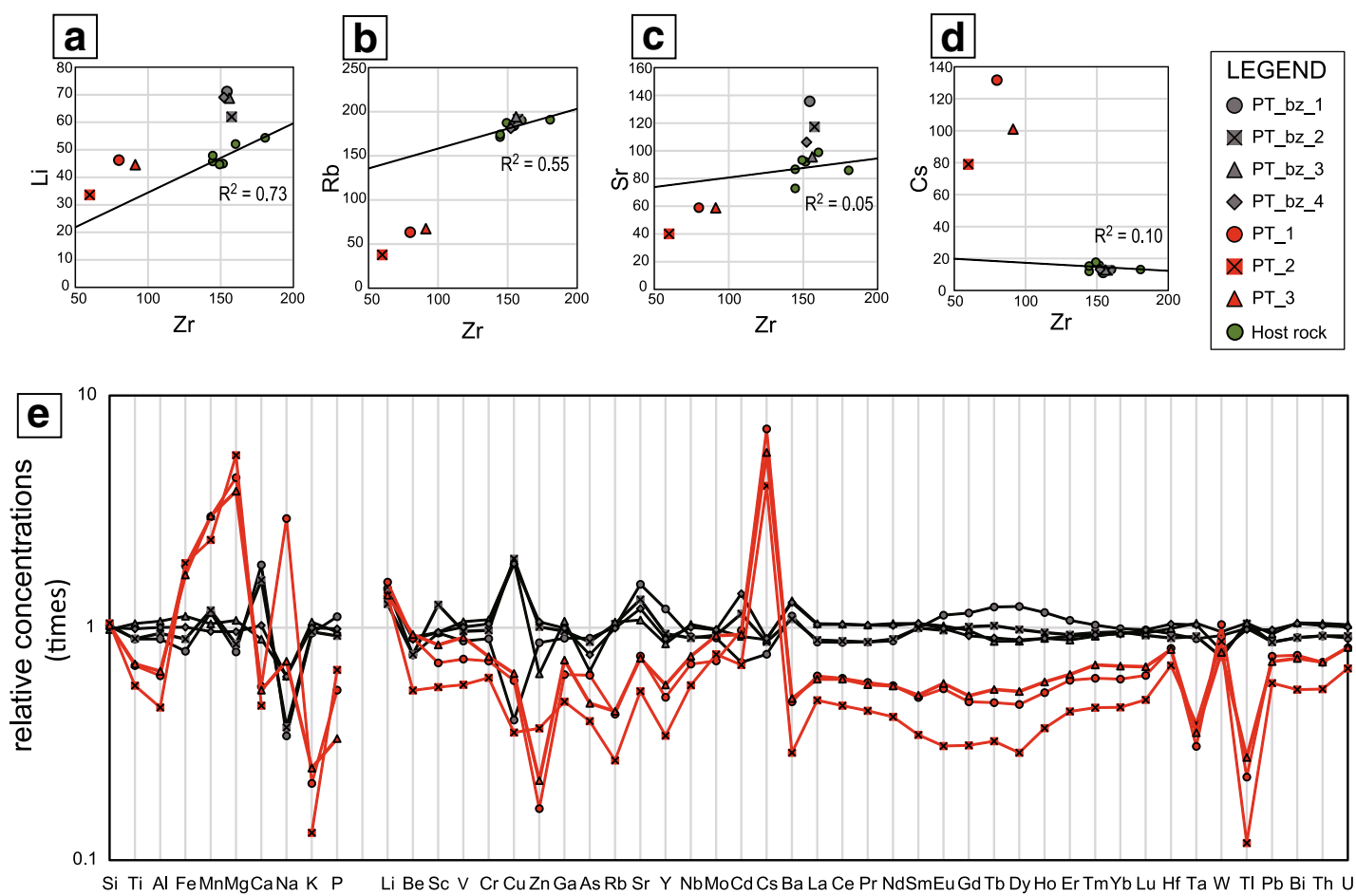

Minor fault in footwall
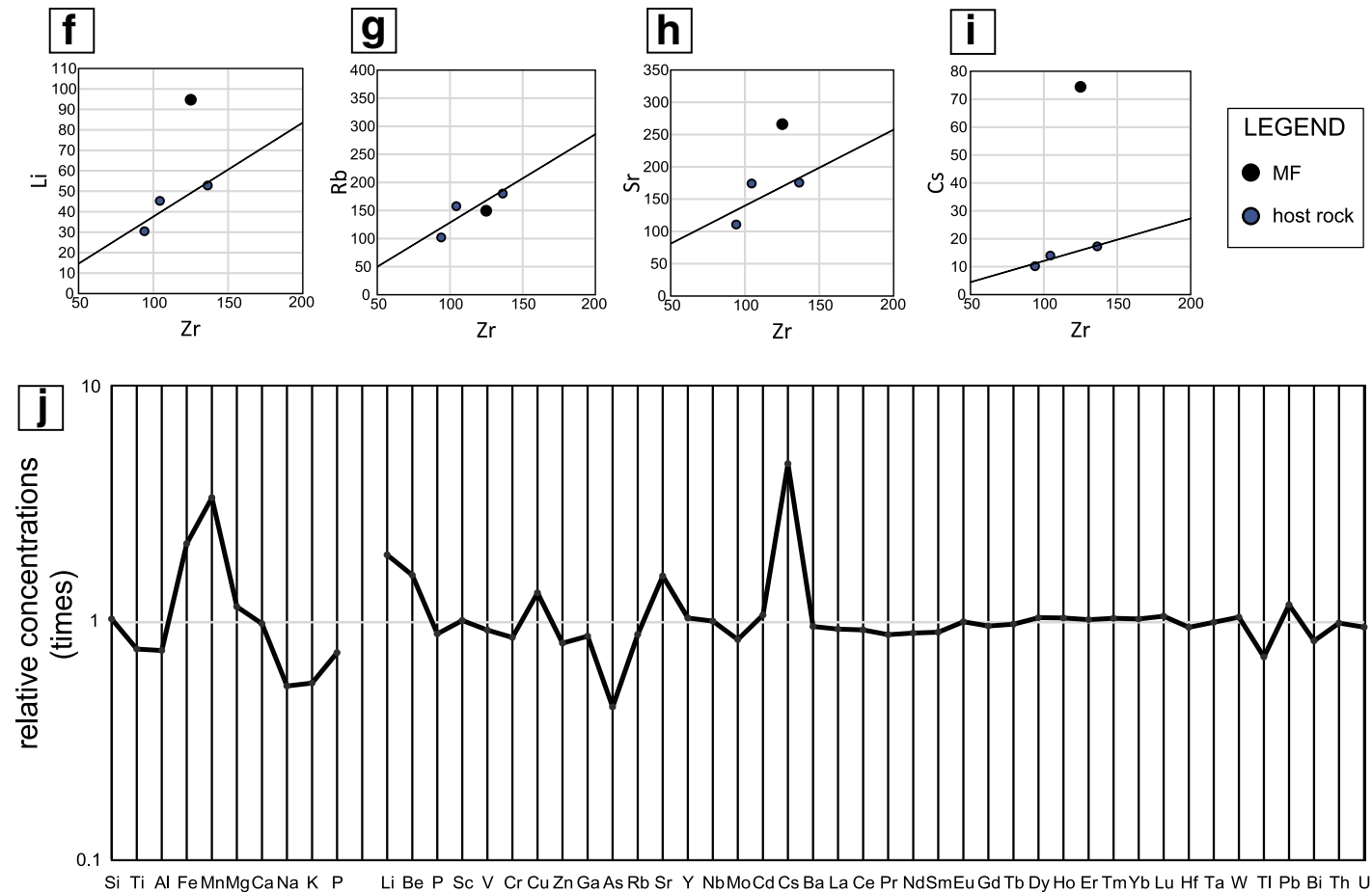

Fig. 7 (See legend on next page.) 
(See figure on previous page.)

Fig. 7 Major and trace element composition of the PSZ and a minor fault. (a-d, $\mathbf{f}-\mathbf{i})$. Li, Rb, Sr, and Cs concentrations plotted against Zr concentration for the pseudotachylyte and blackened zone in PSZ (a-d) and a minor fault in the footwall ( $\mathbf{f}-\mathbf{i})$. The regression line defined by the host rocks concentrations. $\mathbf{e}$, $\mathbf{j}$ Major and trace element compositions of pseudotachylyte and blackened zone (e), and footwall minor fault (j) with respect to the expected value calculated by element compositions of host rock. The relative concentrations from the expected value were calculated as follows: [(concentration of fault rock - expected value)/expected value]

material filling the shear plane and describe its textural and chemical features.

Pseudotachylyte is approximately $1.2-1.5 \mathrm{~mm}$ in thickness and has a well-defined boundary with the surrounding blackened zone (Fig. 4a). The matrix of the pseudotachylyte shows extremely bright color compared to the surroundings: yellow to orange and in some places brown to black color. This color variation reflects the development of flow texture. A large number of fragments having a major axis of $100 \mu \mathrm{m}$ or less are present in the pseudotachylyte (Fig. 5a, b). Relatively large fragments, i.e., particle sizes of several hundred micrometers, are uncommonly included in the pseudotachylyte. A lenticular-shaped quartz fragment and quartz grains surrounding the pseudotachylyte were intensively cracked without showing any offsets across the cracks (Fig. 5b), suggesting that these quartz grains experienced a short-time heating/cooling event to form thermal cracks.

As a result of SEM image observation and EPMA element mapping on the pseudotachylyte, we determined that quartz particles selectively remained in the shear plane, but particle sizes are obviously smaller in the pseudotachylyte compared to other parts of the PSZ (Fig. 6d). Fe-rich particles with sizes of approximately $10-20 \mu \mathrm{m}$ in diameter are scattered throughout pseudotachylyte (Figs. 5c, d and 6d). In addition, embayment structures are observed in quartz particles, which are surrounded in concentrically shaped cracks (Fig. 5c, d). The EPMA element maps of Al (Fig. 6a), K (Fig. 6b), and $\mathrm{Mg}$ (Fig. 6c) reflect the presence of flow texture and residual phyllosilicate particles within the pseudotachylyte matrix, while the distribution of $\mathrm{Mg}$ is complementary.

\section{Geochemical features}

Element mapping revealed that a reduction of $\mathrm{Mg}$ and $\mathrm{Na}$ and a slight enrichment of $\mathrm{K}$ and $\mathrm{Al}$ occurred in the blackened zone compared with the weakly foliated cataclasite (Fig. $4 \mathrm{~b}$ ). In the blackened zone, $\mathrm{Mg}$ and $\mathrm{Ca}$ are locally more concentrated than in the weakly foliated cataclasite. In the pseudotachylyte, an increase of $\mathrm{Mg}$ and a decrease of $\mathrm{Ca}, \mathrm{Na}, \mathrm{K}$, and $\mathrm{Al}$ are evident. The decrease of $\mathrm{Na}$ is more pronounced than in the blackened zone. In addition, regions of concentration $\mathrm{Si}$ are scattered. However, from the result of more magnified element mapping of the pseudotachylyte, there are some areas where $\mathrm{Al}$ and $\mathrm{K}$ are concentrated in the shear plane, and these regions appear to define a flow-like pattern. In contrast, reduction of $\mathrm{Mg}$ concentration parallels the increase in $\mathrm{Al}$ and $\mathrm{K}$ (Fig. 6a-c).

Major and trace element compositions obtained in this study are summarized in Additional file 2: and Additional file 3. By plotting the content of each major and trace element against $\mathrm{Zr}$ concentration, we estimated compositional deviations for the pseudotachylyte and the blackened zone samples relative to the host rocks, by following the method developed by Hamada et al. (2011). Because $\mathrm{Zr}$ is depleted in quartz and feldspars but enriched in clay-rich matrix, the chemical variation of sediments caused by varied mixing ratio between sandy and argillaceous components generally forms a systematic linear trend in the element versus $\mathrm{Zr}$ diagram. $\mathrm{Zr}$ is also known to be fluid-immobile, thus useful for estimating the original composition of the rock that has undergone fluid-rock interactions. First, we estimated "expected" source rock compositions of the pseudotachylyte and the blackened zone by calculating the concentration at a given $\mathrm{Zr}$ concentration for each sample along the regression line (black line of Fig. $7 \mathrm{a}-\mathrm{d}$ ) of the host rock composition. We then normalized the compositions of pseudotachylyte and blackened zone material with respect to their expected values. Figure $7 \mathrm{e}$ shows the enrichment or depletion of elements in pseudotachylyte and blackened zone relative to these expected values.

Table 1 Comparison of fault rock chemical composition anomaly in this study and other fields

\begin{tabular}{|c|c|c|c|c|c|}
\hline & Ishikawa et al. (2008) & Hamada et al. (2011) & Honda et al. (2011) & Yamaguchi et al. (2014) & This research \\
\hline Location & $\begin{array}{l}\text { Chelungpu fault, } \\
\text { Taiwan }\end{array}$ & $\begin{array}{l}\text { Emi accretionary prism, } \\
\text { Boso }\end{array}$ & $\begin{array}{l}\text { Kure mélange, } \\
\text { Shimanto }\end{array}$ & $\begin{array}{l}\text { Pasagshak Point thrust, } \\
\text { Kodiak }\end{array}$ & $\begin{array}{l}\text { Nobeoka Thrust, } \\
\text { Shimanto }\end{array}$ \\
\hline $\begin{array}{l}\text { Background temperature } \\
\left({ }^{\circ} \mathrm{C}\right)\end{array}$ & - & $50-75$ & $50-250$ & 250 & 250 \\
\hline Increase & $\mathrm{Sr} \mathrm{Ba}$ & $\mathrm{Cr} \mathrm{Ni} \mathrm{Sr} \mathrm{Ba}$ & Sr La Pb Sm & Li Sr La & Li Cs \\
\hline Decrease & $\mathrm{Li} R b \mathrm{Cs}$ & Li As Rb Cs & LiCSRb & $R b C s$ & All elements \\
\hline
\end{tabular}


Although deviations from host rock compositions are not as large as those for pseudotachylyte (PT), enrichment of $\mathrm{Ca}, \mathrm{Li}, \mathrm{Cu}$, and $\mathrm{Sr}$ and depletion of $\mathrm{Na}$ is evident for samples analyzed from the blackened zone (PT_BZ). In pseudotachylyte, enrichment of $\mathrm{Fe}, \mathrm{Mn}, \mathrm{Mg}, \mathrm{Li}$, and $\mathrm{Cs}$, depletion of $\mathrm{Ti}, \mathrm{Al}, \mathrm{Ca}, \mathrm{K}$, and $\mathrm{P}$, and all trace elements except W were obtained. Notably, in pseudotachylyte, the concentration of $\mathrm{Mg}$ is roughly 3.8-5.5 times and $\mathrm{Cs}$ is 4.0-7.1 times larger than that of the host rock.

Major and trace element compositions of the analyzed minor fault in the footwall show similar geochemical behavior as observed in the pseudotachylyte of the PSZ (Fig. 7j). In this setting, Cs concentration is 4.6 times that measured in the host rock.

\section{Discussion}

\section{Comparison with previous researches}

Fluid-rock interactions along the Chelungpu fault, Taiwan, were investigated by Ishikawa et al. (2008), while the Emi accretionary complex, Boso, the Kure Mélange of the Shimanto belt, and the Pasagshak Point thrust in the Kodiak accretionary prism were studied by Hamada et al. (2011), Honda et al. (2011), and Yamaguchi et al. (2014), respectively. Table 1 compares the element redistribution patterns derived from this work to those obtained from previous researches. The tendency for the concentrations of $\mathrm{Li}, \mathrm{Rb}$, and $\mathrm{Cs}$ to be reduced while the concentration of $\mathrm{Sr}$ is increased in the previous studies reflects the fact that $\mathrm{Li}, \mathrm{Rb}$, and $\mathrm{Cs}$ are easily dissolved from sediments in fluids above $350{ }^{\circ} \mathrm{C}$. In contrast, as shown by the results of hydrothermal experiments using sediments (You et al. 1996), $\mathrm{Sr}$ is incorporated into rocks. This tendency tracks increases in pore fluid temperature due to frictional heating and generates thermal pressurization. On the other hand, in the PSZ of the Nobeoka Thrust, the increase in $\mathrm{Li}$ and Cs and the reduction of all other elements, and, in particular, an approximately sevenfold increase of Cs, is characteristic (Fig. 7). Although this result is different from that obtained in previous studies, it is in agreement, in terms of increasing $\mathrm{Li}$ concentration, with Yamaguchi et al. (2014). Regarding the enrichment of Li, Yamaguchi et al. (2014) estimate that reactions with fluids containing a high content of $\mathrm{Li}$ occurred at seismogenic depths. In this study, it is suggested that $\mathrm{Li}$ and $\mathrm{Cs}$ are concentrated due to the similarity of temperatures experienced by the Kodiak accretionary complex and the Nobeoka Thrust. Such element redistribution patterns are considered to be markers of past fluid flow events.

\section{Estimation of composition of fluid that reacted with pseudotachylyte}

Data presented earlier suggest that changes in elemental concentrations occurred by an influx of fluid into the fault rock containing pseudotachylyte. To identify the timing at which the reaction and influx of fluid occurred, the following five possibilities were examined: (1) coseismic fluid infiltration and reaction with fine-grained comminuted particles prior to the formation of frictional melt, (2) coseismic reaction and fluid infiltration at the time of frictional melting, (3) postseismic reaction and fluid infiltration into glassy matrix after the formation of pseudotachylyte, (4) postseismic reaction and fluid infiltration with devitrified clay matrix immediately after (3), and (5) reaction and fluid infiltration after cessation of movement on the Nobeoka Thrust and its erosional exhumation. Among these five possibilities, since the spike
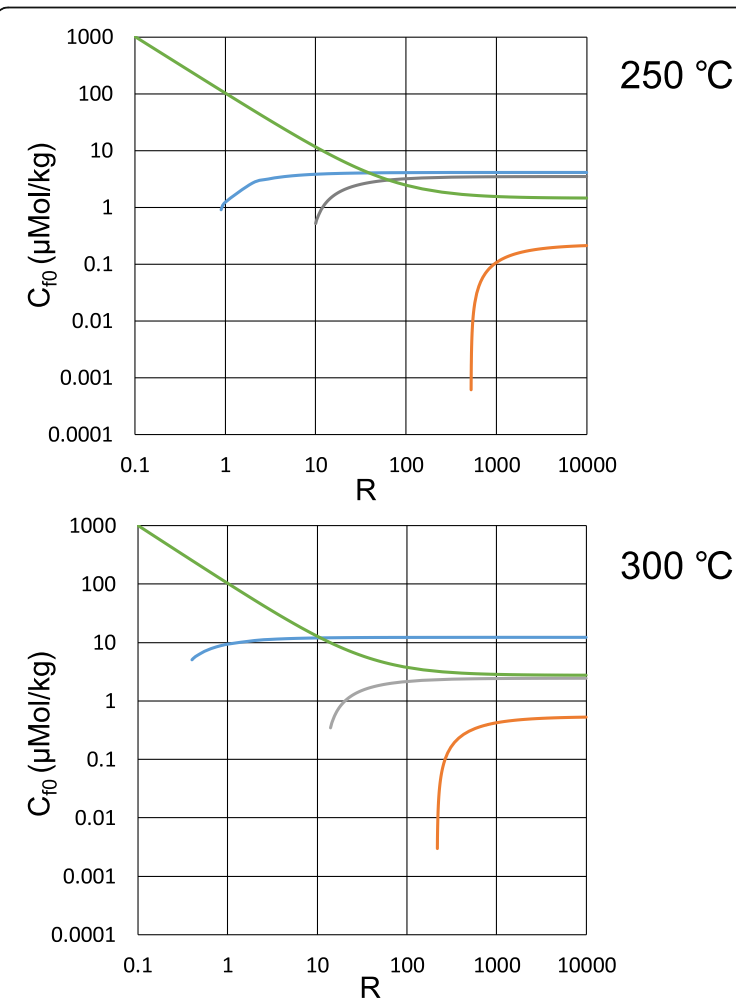

$300{ }^{\circ} \mathrm{C}$

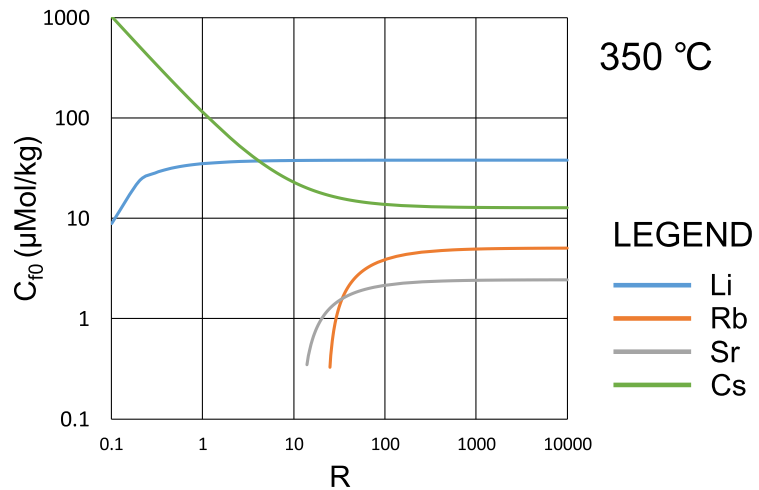

Fig. 8 Estimated Li, Rb, Sr, and Cs concentrations of fluid that had reacted with the pseudotachylyte. The vertical axis shows concentration $C_{f 0}$, and the horizontal axis shows fluid-rock mass ratio $R$ at temperatures of 250,300 , and $350^{\circ} \mathrm{C}$, respectively 
Table 2 Comparison of trace element composition in Okinawa Trough, Guaymas Basin (Gamo 1995), Escanaba Trough (Campbell et al. 1994), and Nankai Trough (Nishio et al. 2015)

\begin{tabular}{lllll}
\hline Okinawa Trough & Guaymas Basin Ridge & Escanaba Trough & & Nankai Trough \\
\hline Temperature $\left({ }^{\circ} \mathrm{C}\right)(\mu \mathrm{mol} / \mathrm{kg})$ & 320 & - & $108-217$ & 240 \\
$\mathrm{Li}$ & 2500 & 1080 & 1268 & 168 \\
$\mathrm{Rb}$ & 360 & 86 & 92.5 & 133 \\
$\mathrm{Sr}$ & 94 & 253 & 209 & 39.8 \\
$\mathrm{Cs}$ & - & 0.3 & 6.8 & - \\
\hline
\end{tabular}

of $\mathrm{Li}$ and $\mathrm{Cs}$ occurs also in the minor fault in the footwall where frictional melting did not occur, the possibility of (2) and (3) are excluded. In addition, since the elemental redistribution pattern commonly found in the pseudotachylyte and footwall minor fault is not observed in the blackened zone and the weakly foliated cataclasite in the PSZ, the possibility of (5) is unlikely. Therefore, the fluid infiltration producing the reaction resulting in the increase in $\mathrm{Li}$ and $\mathrm{Cs}$ concentrations is assumed to have occurred prior or after formation of the pseudotachylyte (i.e., (1) or (4) above).

In order to estimate the concentrations of $\mathrm{Li}, \mathrm{Rb}, \mathrm{Sr}$, and $\mathrm{Cs}$ in the infiltrating fluid under the conditions of
(1) or (4), we completed the following exercise. First, assuming that reaction equilibrium is established between the infiltrating fluid and the fault rock, the concentration of an element in the fault rock after the reaction is represented by

$$
C_{s}=D \frac{C_{s 0}+R \cdot C_{f 0}}{R+D}
$$

where $C_{f 0}$ is the concentration of the trace element in the fluid prior to the reaction, $C_{\mathrm{s}}$ is the concentration of the trace element of the fault rock after the reaction, $C_{s 0}$ is the concentration of the trace element in

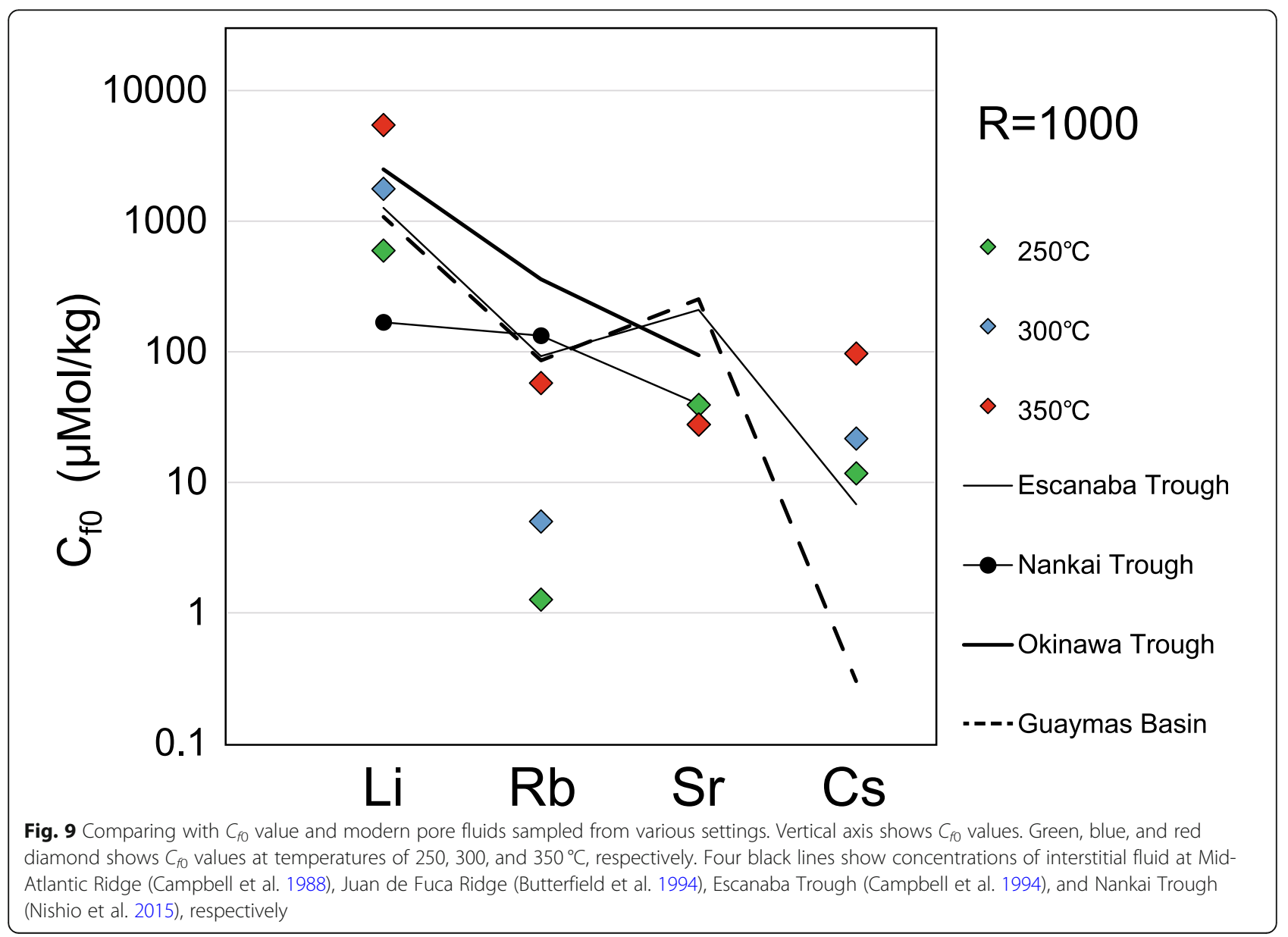


the host rock prior to the reaction, $R$ is the fluid/rock mass ratio, and $D$ is the distribution coefficient $(D=$ $C_{s} / C_{\mathrm{f}}$ ) (Ishikawa et al. 2008). Isolating $C_{f 0}$ results in

$$
C_{f 0}=\frac{C_{s}(R+D)-D \cdot C_{s 0}}{D \cdot R}
$$

The value of the partition coefficient $D$ of each element depends on the temperature, and according to Ishikawa et al. (2008), the value estimated from data at $250{ }^{\circ} \mathrm{C}, 300^{\circ} \mathrm{C}$, and $350^{\circ} \mathrm{C}$ in the hydrothermal experiments by You et al. (1996) can be used. The value of the fluid/rock ratio $R$ was varied from 0.1 to 10,000 with respect to $D$ at each temperature, and the value of the trace element concentration $C_{f 0}$ in the fluid before the reaction was modeled (Fig. 8). As a result, the concentrations of $\mathrm{Rb}$ in the fluid that had reacted with pseudotachylyte at $250^{\circ} \mathrm{C}, 300^{\circ} \mathrm{C}$, and $350^{\circ} \mathrm{C}$ showed a positive value when the $R$ value was 522,216 , and $\geq 24$, respectively. These results indicate that in the pseudotachylyte, the reaction occurred under the influence of a large amount of infiltrating fluid. For example, $R$ is $>522$ at $250{ }^{\circ} \mathrm{C},>216$ at $300^{\circ} \mathrm{C}$, and $\geq 24$ at $350^{\circ} \mathrm{C}$. On a short timescale of several seconds, e.g., from the start of faulting to the occurrence of frictional melting and heating (possibility (1)), it is extremely difficult for such a large amount of fluid to react with a fault rock. Therefore, the fixation of $\mathrm{Li}$ and Cs must have occurred as the result of fluid flowing through the pseudotachylyte, which was partially devitrified after faulting, and the granular zone of the minor fault in the footwall (possibility (4)).
However, the value of the partition coefficient used to perform this calculation was derived from hydrothermal experiments on the muddy sediments of the Nankai Trough reported by You et al. (1996), and this value can take on quite different values depending on the mineral phase contained in the rock. At present, examples of hydrothermal experiments using such sediment reported in the literature are restricted to You et al. (1996) and James et al. (2003), and there is no experimental data exceeding $350^{\circ} \mathrm{C}$. Therefore, in the future, it will be necessary to further determine the partition coefficient of each mineral from the hydrothermal experiment including the higher temperature range in order to further improve the accuracy of research estimating fluid-rock interactions.

\section{Character of fluid that reacted with fault rock containing pseudotachylyte}

From Fig. 8, it can be recognized that the $C_{f 0}$ values of $\mathrm{Li}, \mathrm{Rb}, \mathrm{Sr}$, and $\mathrm{Cs}$ estimated from the composition of pseudotachylite converge to a fixed value when $R \geq$ 1000. The value of $C_{f 0}$ at $R=1000$ was compared with the concentration of fluid obtained from the Okinawa Trough, Guaymas Basin (Gamo 1995), Escanaba Trough in the southern part of the Gorda Ridge (Campbell et al. 1994), and the Nankai Trough (Nishio et al. 2015) (Table 2). The Okinawa Trough, Guaymas Basin, and Nankai Trough are covered by thick sections of terrigenous sediments, and samples were taken from erupted hydrothermal fluids. The fluid sample from the Nankai Trough was taken from the pore water within a borehole core sample drilled through a mud volcano. As a result,

\section{pseudotachylyte}

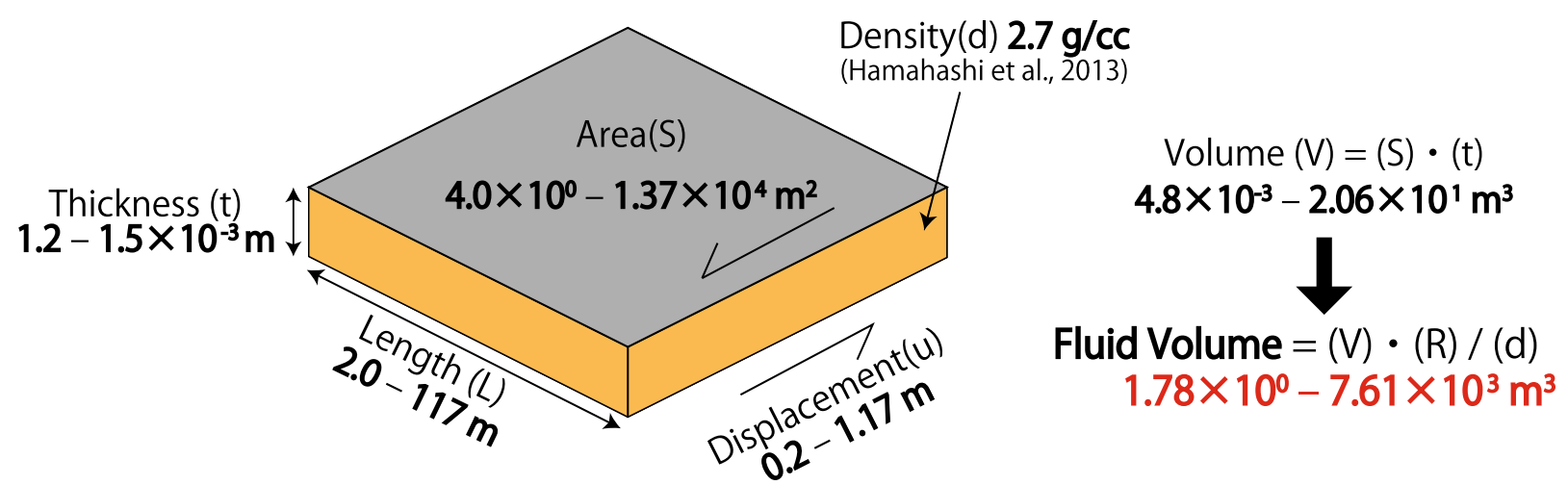

Fig. 10 Estimation of fluid volume that reacted with fault rock containing pseudotachylyte. Fault displacement of pseudotachylyte was estimated from a plot of fault thickness vs. displacement (Di Toro and Pennacchioni 2005). Fault length was estimated from fault displacement by the plot of fault displacement and length (Kim and Sanderson 2005). The fault area was assumed to be the square of the fault length, and the volume was calculated by multiplying the fault area by the thickness. Finally, the fluid volume was calculated from the calculated volume using the $R$ value (1000 for simplicity) and the density of the fault rock 
in the Nobeoka Thrust, $\mathrm{Li}$ concentrations $\left(C_{f 0}\right)$ in the fluid are similar or relatively higher, and Cs concentrations $\left(C_{f 0}\right)$ are clearly higher than those in other regions (Fig. 9). Therefore, we conclude that pseudotachylyte reacted with a $\mathrm{Li}$ - and $\mathrm{Cs}$-rich fluid.

\section{Hydrothermal alteration of pseudotachylyte}

Regarding the concentrations of major elements in the pseudotachylyte, the concentrations of $\mathrm{Mg}, \mathrm{Mn}$, and $\mathrm{Fe}$ are increased compared to the host rock, and in particular $\mathrm{Mg}$ and $\mathrm{Fe}$ enrichments are presumed to be caused by a concentration of clay minerals. It is presumed that the increase of clay minerals in pseudotachylyte and the concomitant concentration of $\mathrm{Mg}, \mathrm{Fe}$, and $\mathrm{Cs}$, along with the almost homogeneous decrease of the concentrations of Ti, Sc, Cr, Y, Nb, REE (La-Lu), Hf, and Th, is likely the result of the mass addition of $\mathrm{Mg}, \mathrm{Fe}$, and $\mathrm{H}_{2} \mathrm{O}$ during intense hydrothermal alteration. Similarly, pseudotachylyte in the hanging wall shear zone of the Nobeoka Thrust is, compared to the host rock, enriched in $\mathrm{Mg}, \mathrm{Al}$, and $\mathrm{Fe}$ and contains palygorskite (Okamoto et al. 2006). Pseudotachylyte within the hanging wall shear zone is characterized by a chemical composition similar to that obtained for pseudotachylyte analyzed during this research. Therefore, it is possible that pseudotachylyte analyzed during this study also was hydrothermally altered after faulting, not only within the PSZ, but also in the hanging wall shear zone.

\section{Estimation of fluid volume}

Here, we estimate fluid volume that had reacted with the fault rock based on pseudotachylyte volume estimated by empirical relationships among pseudotachylyte thickness, fault displacement, fault length (Di Toro and Pennacchioni 2005; Kim and Sanderson 2005), and fluid/rock ratio. Pseudotachylyte in the PSZ of the Nobeoka Thrust PSZ is contained within the $\sim 1.5$ $\mathrm{cm}$-thick blackened zone and is $\sim 1.2-1.5 \mathrm{~mm}$ in thickness. Meanwhile, the displacement of a $1.4-1.5 \mathrm{~mm}$ thick layer of pseudotachylyte within the Gole Larghe

\section{Postseismic}

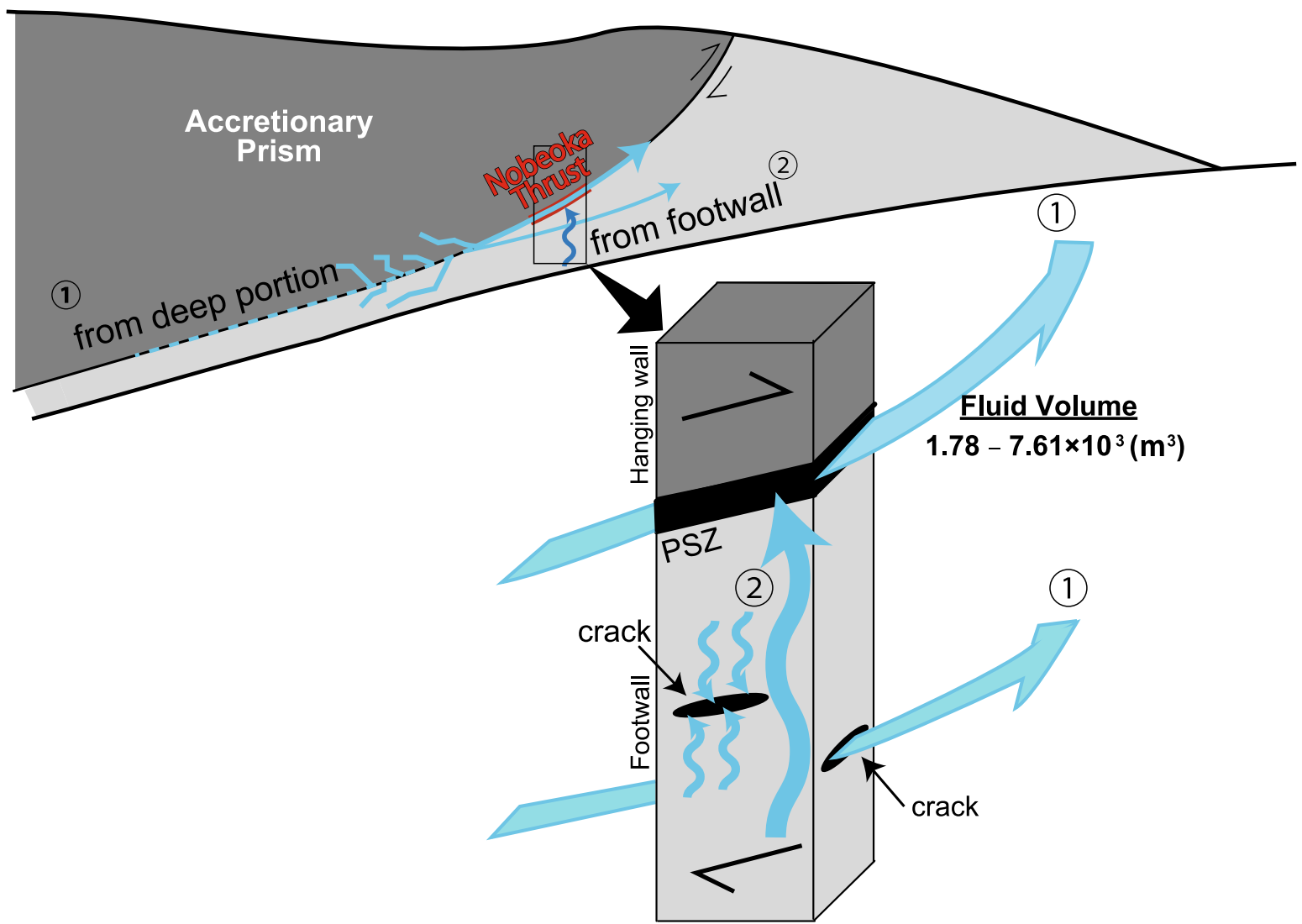

Fig. 11 Schematic illustration showing postseismic fluid discharge along the Nobeoka Thrust. The upper figure shows a cross-section of the subduction zone. The lower figure shows fluid supply from deep reservoir or footwall mélange. The fluid that reacted with the fault rocks was enriched in Li and Cs, and the fluid volume was estimated to be $1.78-7.61 \times 10^{3} \mathrm{~m}^{3}$ 
fault in Italy, formed at depths of $9-11 \mathrm{~km}$ and temperatures of $250-300^{\circ} \mathrm{C}$, was $200-1170 \mathrm{~mm}$ (Di Toro and Pennacchioni 2005). Assuming that pseudotachylyte in the Nobeoka Thrust PSZ has similar thicknessdisplacement relationship as that of the Gole Larghe fault, the displacement $(d)$ of the pseudotachylyte is also roughly estimated to be $200-1170 \mathrm{~mm}$ since the thickness $(t)$ of pseudotachylyte in the Nobeoka Thrust PSZ was $1.2-1.5 \mathrm{~mm}$. There is an empirical relationship between fault length and fault displacement. Kim and Sanderson (2005) showed that the relationship of fault displacement $(u)$ /fault length $(L)$ for a thrust fault is roughly $10^{-1}-10^{-2}$. Assuming a similar value for the Nobeoka Thrust, and a $u$ value of $200-1170 \mathrm{~mm}$, it is estimated that $L$ is $2.0 \times 10^{2}-1.170 \times 10^{5} \mathrm{~mm}$. The fault area, $S$, is the square of $L$. Therefore $S$ is $2.0^{2}-117^{2} \mathrm{~m}^{2}$ and $t$ is $1.2-1.5 \mathrm{~mm}$. The volume $V$ of the fault rock is $4.8 \times 10^{-3}-2.05 \times 10^{1} \mathrm{~m}^{3}$.

We assumed that the water/rock ratio, $R$, is 522, 216, and $\geq 24$ at the fluid temperatures of $250{ }^{\circ} \mathrm{C}, 300^{\circ} \mathrm{C}$, and $350^{\circ} \mathrm{C}$, respectively. As noted earlier, the concentration of $\mathrm{Li}, \mathrm{Rb}, \mathrm{Sr}$, and $\mathrm{Cs}$ in the fluid, $C_{f 0}$, converges to a fixed value when $R \geq 1000$, so the following consideration implies $R$ is 1000 . Assuming that the density $d$ of the fault rock containing pseudotachylyte is $2.7 \mathrm{~g} / \mathrm{cc}$ (Hamahashi et al. 2013) and the density of the fluid is $1.0 \mathrm{~g} / \mathrm{cc}$, the minimum volume of the fluid that had reacted with the fault rock is $V \times R / d=1.78 \times 10^{\circ} \mathrm{m}^{3}(L=2.0 \mathrm{~m}, t=1.2$ $\mathrm{mm})$. On the other hand, in the case of $L=117 \mathrm{~m}$ and $t$ $=1.5 \mathrm{~mm}$, it is estimated to be $7.61 \times 10^{3} \mathrm{~m}^{3}$ at the maximum (Fig. 10).

\section{Fluid reservoirs}

Fluid that reacted with the Nobeoka Thrust PSZ and the minor fault in the footwall probably was supplied from the following two reservoirs: (1) the fault was connected to a fracture network that was temporally linked to a fluid source of deep origin and (2) fluid was supplied from the pores within the footwall mélange (Fig. 11). In the case of (1), the volume of the fluid that reacted with the pseudotachylyte is estimated to be 1.78 to $7.61 \times 10^{3}$ $\mathrm{m}^{3}$, which is equal to the minimal volume of the potential fluid reservoir. The results of a seismic reflection survey (Park et al. 2002) and a waveform tomographic study (Tsuji et al. 2014) suggest that the scale of a high pore pressure zone in the deep portion of the megasplay fault of the Nankai Trough extends on the order of $\mathrm{km}$, both horizontally and vertically. Therefore, a fluid reservoir with a minimum value of 1.78 to $7.61 \times 10^{3} \mathrm{~m}^{3}$ along the deeper portion of the Nobeoka Thrust is plausible. In the case of (2), the footwall mélange (41.3$80 \mathrm{~m}$ ) has a minimum porosity $(\phi)$ of $7.6 \%$ according to geophysical logging data (Hamahashi et al. 2013). This porosity is maintained to a depth of $255 \mathrm{~m}$, the bottom of the borehole core sample (Hamahashi et al. 2015). Assuming that the fluid was supplied from the pores in the mélange to the fault rock, the thickness of the feeder zone $\left(D_{f}\right)$ is estimated from the following equation:

$$
D_{f}=\frac{R \cdot t}{\phi},
$$

where $R, t$, and $\phi$ are water/rock ratio, pseudotachylyte thickness, and porosity, respectively.

When $t=1.2 \mathrm{~mm}, R=1000$, and $\phi=7.6 \%, D_{f}$ can be estimated to be $15.79 \mathrm{~m}$, and when $t=1.5 \mathrm{~mm}, D_{f}$ is estimated to be $19.74 \mathrm{~m}$. From the geophysical logging data of NOBELL, the porosity is nearly constant down to hundreds of meters below the PSZ (Hamahashi et al. $2015)$; therefore, the value of $D_{f}$ is well within the allowable range.

In spite of the large volume of the fluid, element redistribution is only recorded in the fault rocks, not in the host mélange. This fact suggests that the postseismic fluid infiltration occurred on a relatively short time scale: i.e., glassy, reactive pseudotachylyte was devitrified but low-reactive host mélange was not affected. Such an abrupt postseismic fluid discharge proposed in this study is consistent with the results of studies on veins along the Nobeoka Thrust (Yamaguchi et al. 2011; Otsubo et al. 2016; Kawasaki et al. 2017; Saishu et al. 2017). Such a fluid flow pattern is expected in the modern megasplay fault at $\sim 5 \mathrm{~km}$ below the seafloor of the Nankai Trough.

\section{Conclusions}

From the results of structural observation and chemical composition analysis of the fault rock in the PSZ of the Nobeoka Thrust, the following points are evident.

1. The PSZ at the boundary between the hanging wall and the mélange is made up of weakly foliated cataclasite. Pseudotachylyte is another prominent feature in the PSZ.

2. Common chemical composition anomalies, such as high Li- and Cs-concentration, were observed both in the pseudotachylyte in the PSZ and in a minor fault of the footwall. The compositional anomalies were caused by reaction with a fluid containing high concentration of Li and Cs compared to its surroundings which flowed through fractures of the fault after the movement had ceased (Fig. 11). The concentration of $\mathrm{Cs}$ in the pseudotachylyte was 4.1-7.2 times the concentration of Cs in the host rock. For the minor fault in the footwall block, this value is 4.7. This increase in Cs is presumed to be due to its fixability which increased due to clay mineral formation by the hydrothermal alteration of pseudotachylyte. In addition, the increase of clay in 
pseudotachylyte and the concomitant increase in the concentration of $\mathrm{Mg}, \mathrm{Fe}$, and $\mathrm{Cs}$, and the parallel decrease in the concentration of elements such as Ti, Sc, Cr, Y, Nb, REE ( $\mathrm{La}-\mathrm{Lu}$ ), Hf, and Th are also estimated to be the result of the mass addition of $\mathrm{Mg}, \mathrm{Fe}$, and $\mathrm{H}_{2} \mathrm{O}$ during intense hydrothermal alteration.

3. The fluid volume of the fault rock containing pseudotachylyte is estimated to be 1.78 to $7.61 \times$ $10^{3} \mathrm{~m}^{3}$. It is presumed that this fluid volume was supplied from deeper portions of the Nobeoka Thrust, or the mélange of the footwall block or both (Fig. 11). A large amount of fluid must have been supplied through the fracture system which was formed postseismically in the megasplay fault zone under high pore pressures.

\section{Additional files}

Additional file 1: Sampling point in a tip of thin section and PSZ polished slabs. Sample name of [PT_1-3], [PT_bz_1-4] and [PT_host_1-6] correspond to pseudotachylyte, blackened zone and host rock respectively $(a, b)$. Sample name of [PSZ_1-3] for XRF analysis were taken from yellow frames of the picture of the PSZ polished slabs (c). (PDF $364 \mathrm{~kb}$ )

Additional file 2: Sample list, data of depth, and chemical composition of PSZ and footwall minor fault. (XLSX $31 \mathrm{~kb}$ )

Additional file 3: Data of depth, and chemical composition of PSZ and footwall minor fault. (XLSX $43 \mathrm{~kb}$ )

\section{Abbreviations}

EPMA: Electron probe micro analyzer; ICP-MS: Inductively coupled plasmamass spectrometer; JAMSTEC: Japan Agency for Marine-Earth Science and Technology; KCC: Kochi Core Center; NOBELL: Nobeoka Thrust Drilling Project; PSZ: Principal Slip Zone; XRF: X-ray fluorescence

\section{Acknowledgements}

This research was supported by the Center for Advanced Marine Core Research, Kochi University (CMCR) Nationwide Joint Use System (17B072). We would like to thank Makoto Otsubo, Ayumu Miyakawa, Hugues Raimbourg and Olivier Fabbri for useful discussions. We are grateful to Tatsuya Kawai for assistance with using GEOMILL 326 and ICP-MS installed in Kochi Core Center. We also thank two anonymous reviewers and associate editor Masataka Kinoshita for their constructive comments.

\section{Funding}

This research was financially supported by JSPS KAKENHI Grant Number JP15H05717, JSPS KAKENHI Grant Number JP16K13892, JSPS KAKENHI Grant Number JP16H04066, JSPS KAKENHI Grant Number JP17H05312, JSPS KAKENHI Grant Number JP18H03732.

\section{Availability of data and materials}

Please contact author for data requests.

\section{Authors' contributions}

$\mathrm{RH}$ conducted all analyses and observations and wrote the initial manuscript. AY designed the overall project and revised manuscript. RF and $\mathrm{YH}$ contributed to the core sample description and mineralogical interpretation. NO assisted FE-SEM and EPMA observations. YK assisted the geochemical interpretation especially in the early stage of the research. GK advised sampling strategy. JA advised the direction of research. TI assisted geochemical analyses, interpretation, and manuscript writing. All authors read and approved the final manuscript.

\section{Competing interests}

The authors declare that they have no competing interests.

\section{Publisher's Note}

Springer Nature remains neutral with regard to jurisdictional claims in published maps and institutional affiliations.

\section{Author details \\ ${ }^{1}$ Atmosphere and Ocean Research Institute, The University of Tokyo, 5-1-5 Kashiwanoha, Kashiwa, Chiba 277-8564, Japan. ${ }^{2}$ Kochi Institute for Core Sample Research, Japan Agency for Marine-Earth Science and Technology, 200 Monobe Otsu, Nankoku, Kochi 783-8502, Japan. 'Kagoshima University, 1-21-40 Korimoto, Kagoshima City, Kagoshima 890-0065, Japan. ${ }^{4}$ Tokyo University of Marine Science and Technology, 4-5-7 Minatominami, Minato, Tokyo 108-0075, Japan.}

Received: 27 April 2018 Accepted: 25 March 2019

Published online: 25 April 2019

\section{References}

Bizzarri A, Cocco M (2006) A thermal pressurization model for the spontaneous dynamic rupture propagation on a three-dimensional fault: 1. Methodological approach. J Geophys Res 111:B05303

Butterfield DA, McDuff RE, Franklin J, Wheat CG (1994) Geochemistry of hydrothermal vent fluids from middle valley, Juan de Fuca Ridge. In: Mottl MJ, Davis EE, Fisher AT, Slack JF (eds) Proceedings of the ocean drilling program, vol 139. Texas A\&M University, Texas, pp 395-410

Campbell AC, German CR, Palmer MR, Gamo T, Edmond JM (1994) Chemistry of hydrothermal fluid from Escanaba Trough, Gorda Ridge. In: Morton JL, Zierenberg RA, Reiss CA (eds) Geologic, hydrothermal, and biologic studies at Escanaba Trough, Gorda Ridge, Offshore Northern California, Bulletin, 2022. U S Geological Survey, Wisconsin, pp 201-221

Campbell AC, Palmer MR, Klinkhammer GP, Bowers TS, Edmond JM, Lawrence JR, Casey JF, Thompson G, Humphris S, Rona P, Karson JA (1988) Chemistry of hot spring on the Mid-Atlantic Ridge. Nature 335(6):514-519

Di Toro G, Pennacchioni G (2005) Fault plane processes and mesoscopic structure of a strong-type seismogenic fault in tonalites (Adamello batholith, Southern Alps). Tectonophysics 402:55-80

Fukuchi R, Fujimoto K, Kameda J, Hamahashi M, Yamaguchi A, Kimura G, Hamada Y, Hashimoto Y, Kitamura Y, Saito S (2014) Changes in illite crystallinity within an ancient tectonic boundary thrust caused by thermal, mechanical, and hydrothermal effects: an example from the Nobeoka Thrust, southwest Japan. Earth Planets Space 66:116

Gamo T (1995) Wide variation of chemical characteristics of submarine hydrothermal fluids due to secondary modification processes after high temperature water-rock interaction: a review. In: Sakai, H., Nozaki, Y. (Eds.) Biogeochemical Processes and OceanFlux in theWesternPacific. Terra Scientific Publishing, Tokyo, Japan, pp. 425-452.

Hamada Y, Hirono T, Ishikawa T (2011) Coseismic frictional heating and fluid-rock interaction in a slip zone within a shallow accretionary prism and implications for earthquake slip behavior. J Geophys Res 116:B01302

Hamahashi M, Hamada Y, Yamaguchi A, Kimura G, Fukuchi R, Saito S, Kameda J, Kitamura Y, Fujimoto K, Hashimoto Y (2015) Multiple damage zone structure of an exhumed seismogenic megasplay fault in a subduction zone - a study from the Nobeoka Thrust Drilling Project. Earth Planets Space 67:1

Hamahashi M, Saito S, Kimura G, Yamaguchi A, Fukuchi R, Kameda J, Hamada Y, Kitamura Y, Fujimoto K, Hashimoto Y, Hina S, Eida M (2013) Contrasts in physical properties between the hanging wall and footwall of an exhumed seismogenic megasplay fault in a subduction zone - an example from the Nobeoka Thrust Drilling Project. Geochem Geophys Geosyst 14:5354-5370

Honda G, Ishikawa T, Hirono T, Mukoyoshi H (2011) Geochemical signals for determining the slip-weakening mechanism of an ancient megasplay fault in the Shimanto accretionary complex. Geophys Res Lett 38:L06310

Ishikawa T, Tanimizu M, Nagaishi K, Matsuoka J, Tadai O, Sakaguchi M, Hirono T, Mishima T, Tanikawa W, Lin W, Kikuta H, Soh W, Song SR (2008) Coseismic fluid-rock interactions at high temperatures in the Chelungpu fault. Nat Geosci 1:679-683

James RH, Allen DE, Seyfried Jr, WE (2003) An experimental study of alteration of oceanic crust and terrigenous sediments at moderate temperatures (51 to $350^{\circ} \mathrm{C}$ ): insights as to chemical processes in near-shore ridge-flank hydrothermal systems. Geochimica et Cosmochimica Acta, 67, 681-691. 
Kawasaki R, Hamahashi M, Hashimoto Y, Otsubo M, Yamaguchi A, Kitamura Y, Kameda J, Hamada Y, Fukuchi R, Kimura G (2017) Temporal stress variations along a seismogenic megasplay fault in the subduction zone: an example from the Nobeoka thrust, southwestern Japan. Island Arc 26:e12193

Kim YH, Sanderson DV (2005) The relationship between displacement and length of faults: a review. Earth Sci Rev 68:317-334

Kimura G, Hamahashi M, Okamoto S, Yamaguchi A, Kameda J, Raimbourg H, Hamada Y, Yamaguchi H, Shibata T (2013) Hanging wall deformation of a seismogenic megasplay fault in an accretionary prism: the Nobeoka Thrust in southwest Japan. J Struct Geol 52:136-147

Kitajima H, Takahashi M, Otsubo M, Saffer D, Kimura G (2017) Strength and deformation behavior of the Shimanto accretionary complex across the Nobeoka thrust. Island Arc 26:e12192

Kondo H, Kimura G, Masago H, Ohmori-lkehara K, Kitamura Y, Ikesawa E, Sakaguchi A, Yamaguchi A, Okamoto S (2005) Deformation and fluid flow of a major out-of-sequence thrust located at seismogenic depth in an accretionary complex: Nobeoka Thrust in the Shimanto Belt, Kyushu, Japan. Tectonics 24:TC6008

Mase CW, Smith L (1987) Effects of frictional heating on the thermal, hydrologic, and mechanical response of a fault. J Geophys Res 92(B7):6249-6272

Murata A (1998) Duplexes and low-angle nappe structures of the Shimanto Terrane, southwest Japan [in Japanese]. Geol Soc Jpn 50:147-158

Nishio Y, ljiri A, Toki T, Morono Y, Tanimizu M, Nagaishi K, Inagaki F (2015) Origins of lithium in submarine mud volcano fluid in the Nankai accretionary wedge. Earth Planet Sci Lett 414:144-155

Ohmori K, Taira A, Tokuyama H, Sakaguchi A, Okamura M, Aihara A (1997) Paleothermal structure of the Shimanto accretionary prism, Shikoku, Japan: role of an out-of-sequence thrust. Geology 25:327-330

Okamoto S, Kimura G, Tanizawa S, Yamaguchi H (2006) Earthquake fault rock indicating a coupled lubrication mechanism. eEarth 1:23-28

Okamoto S, Kimura G, Yamaguchi A, Yamaguchi H, Kusaba Y (2007) Generation depth of the pseudotachylyte from an out-of-sequence thrust in accretionary prism geothermobarometric evidence. Sci Drill (1):47-50. https://doi.org/10. 2204/iodp.sd.s01.41.2007.

Otsubo M, Miyakawa A, Kawasaki R, Kimura G (2016) Variation of stress and driving pore fluid pressure ratio using vein orientation along seismogenic megasplay fault - example of Nobeoka Thrust, southwestern Japan. Island Arc 25:421-432

Park JO, Fujie G, Wijerathne L, Hori T, Kodaira S, Fukao Y, Moore GF, Bangs NL, Taira A (2010) A low-velocity zone with weak reflectivity along the Nankai subduction zone. Geology 38(3):283-286

Park JO, Tsuru T, Kodaira S, Cummins P, Kaneda Y (2002) Splay fault blanching along the Nankai subduction zone. Science 297:1157-1160

Rice JR (2006) Heating and weakening of faults during earthquake slip. J Geophys Lett 111:B05311

Saishu H, Okamoto A, Otsubo M (2017) Silica precipitation potentially controls earthquake recurrence in seismogenic zones. Sci Rep 7:13337

Sakaguchi A (1999) Thermal maturity in the Shimanto accretionary prism, southwest Japan, with the thermal change of the subducting slab: fluid inclusion and vitrinite reflectance study. Earth Planet Sci Lett 173:61-74

Sibson RH (1973) Interactions between temperature and pore-fluid pressure during earthquake faulting and a mechanism for partial or total stress relief. Nature 243(126):66-68

Sibson RH (1975) Generation of pseudotachylyte by ancient seismic faulting. Geophys J R astr Soc 43:775-794

Tsuji T, Kamei R, Pratt RG (2014) Pore pressure distribution of a mega-splay fault system in the Nankai Trough subduction zone: insight into up-dip extent of the seismogenic zone. Earth Planet Sci Lett 396:165-178

Yamaguchi A, Cox SF, Kimura G, Okamoto S (2011) Dynamic changes in fluid redox state associated with episodic fault rupture along a megasplay fault in a subduction zone. Earth Planet Sci Lett 302:369-377

Yamaguchi A, Ishikawa T, Kato Y, Nozaki T, Meneghini F, Rowe CD, Moore JC, Tatsumi A, Kimura G (2014) Fluid-rock interaction recorded in black fault rocks in the Kodiak accretionary complex, Alaska. Earth Planets Space 66(1):58

You C-F, Castillo PR, Gieskes JM, Chan LH, Spivack AJ (1996) Trace element behavior in hydrothermal experiments: implication for fluid processes at shallow depths in subduction zones. Earth Planet Sci Lett 140:41-52

\section{Submit your manuscript to a SpringerOpen ${ }^{\odot}$ journal and benefit from:}

- Convenient online submission

- Rigorous peer review

- Open access: articles freely available online

- High visibility within the field

- Retaining the copyright to your article

Submit your next manuscript at $\boldsymbol{\sim}$ springeropen.com 